\title{
Osseous blastomycosis mimicking malignancy
}

\author{
Sammantha Kouba, ${ }^{1}$ Takaaki Kobayashi $\odot{ }^{2}$ Jeffery Meier, ${ }^{2}$ Poorani Sekar ${ }^{2}$
}

${ }^{1}$ Department of Infectious Diseases, University of lowa Hospitals and Clinics, lowa City, Iowa, USA

${ }^{2}$ Department of Internal Medicine, University of lowa Hospitals and Clinics, lowa City, Iowa, USA

\section{Correspondence to}

Dr Sammantha Kouba; Sammantha.Kouba@gmail.com

Accepted 25 July 2020

\section{DESCRIPTION}

A 33-year-old man presented with a 10-month history of left back and flank pain with radiation to his lower extremity. The symptoms started gradually without preceding trauma or activity. $\mathrm{He}$ is a school teacher, living in the Midwestern United States. He noted construction at his workplace for several months prior. Patient eventually saw a primary care physician and completed physical therapy with minimal improvement. He later underwent CT, which revealed mixed lytic and sclerotic appearance to the left iliac wing most consistent with a neoplastic process such as sarcoma myeloma or lymphoma (figure 1). He was referred to our facility for further evaluation by orthopaedic oncology. Physical examination demonstrated tenderness over left iliac wing with normal range of motion of the hip. MRI demonstrated cystic lesions in the left iliac wing, more concerning for infection (figure 2). Fine needle aspiration and biopsy were performed, which revealed necrotising granulomatous inflammation without malignant cells. He underwent incisional biopsy, where copious purulent material was present. Cultures subsequently grew Blastomyces dermatitidis. He was then started on itraconazole. His symptoms improved slowly after the initiation of itraconazole and eventually resolved a few months later. Treatment was continued for 12 months with a repeat MRI at 8 months showing near resolution of prior lesions (figure 3).

Blastomycosis is caused by inhalation of the spores of the dimorphic fungus, $B$. dermatitidis. Blastomycosis is endemic in the Mississippi and Ohio river valleys, the Great Lakes region and the Saint Lawrence Seaway. ${ }^{1}$ Risk factors include living or travelling to an endemic area, and activities

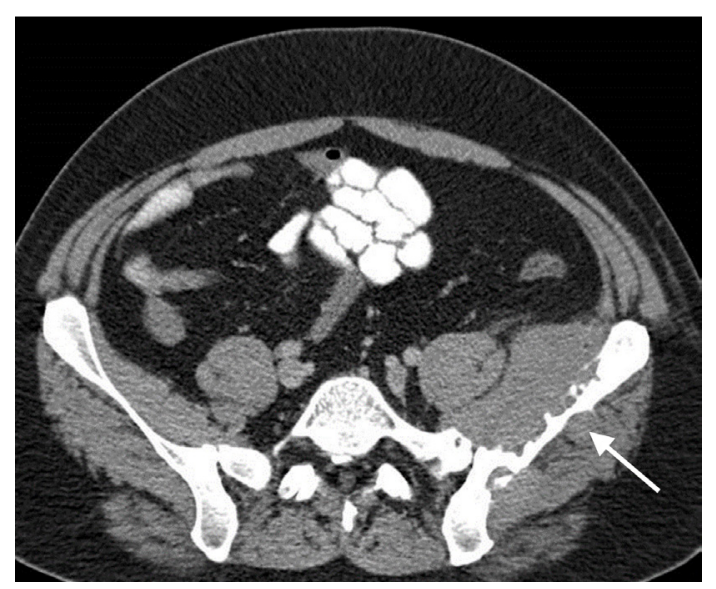

Figure $1 \mathrm{CT}$ of the pelvis revealed mixed lytic and sclerotic appearance to the left iliac wing with abnormal soft tissue in the region of the iliacus.

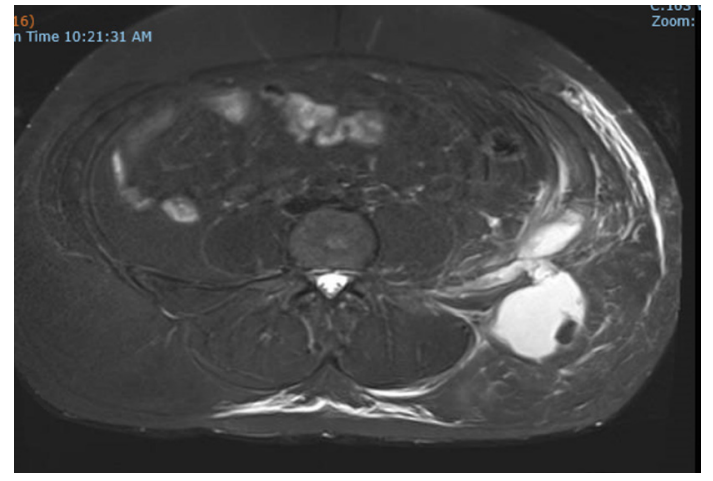

Figure 2 MRI revealed lesion with soft tissue and cystic components centred in the left iliac.

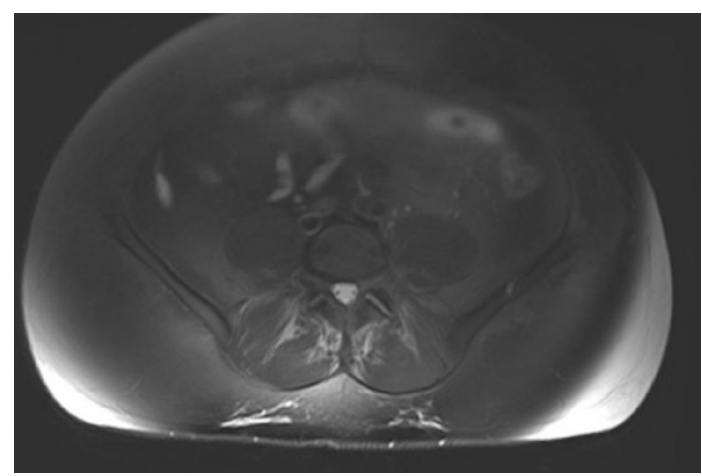

Figure 3 Follow-up MRI demonstrating resolution of prior lesions.

involving soil disruption or water. Symptoms of blastomycosis range from subclinical infection to severe systemic disease. The lungs (91\%) are the most common site of infection, followed by the skin $(18 \%)$, bones $(4 \%)$ and genitourinary tract $(2 \%) .^{2}$ Though any bone can be involved, the most common areas affected include vertebrae, ribs, long bones and skull. ${ }^{3}$ Cutaneous and pulmonary involvements are often seen at $73 \%$ and $64 \%$ in patients with osteoarticular blastomycosis. ${ }^{4}$ Osseous blastomycosis is frequently initially misdiagnosed as malignancy. A high degree of suspicion is needed for accurate diagnosis given delayed recognition of blastomycosis impairs the optimal prognosis from early initiation of appropriate therapy. Definitive diagnosis requires growth of the organism from a clinical specimen. Microscopic visualisation of the broad-based budding yeast forms from the primary specimen would provide a rapid diagnosis, as this is pathognomonic for this condition, however a negative result would not exclude the possibility of blastomycosis. ${ }^{3}$ The detection of Blastomyces antigen in serum and urine has also proven useful in rapid diagnosis. Its sensitivity is 
reported at $93 \%$, whereas the specificity is reported $79 \%$ due to cross-reactivity with Histoplasma. ${ }^{5}$ In addition, antigen levels decline with successful treatment and increase with recurrence. However, our patient had negative antigen in both serum and urine. Although commercially available, serologic antibody testing for blastomycosis is rarely employed due to poor test performance characteristics. ${ }^{3}$ Treatment is recommended for all patients with symptomatic blastomycosis. Oral itraconazole is recommended for mild-to-moderate disseminated extrapulmonary blastomycosis. Amphotericin B is recommended for severe disease. ${ }^{6}$ Treatment duration is based on site, severity of infection and immune status of the patient. Due to the risk

\section{Learning points}

- Blastomycosis is caused by inhalation of spores of the dimorphic fungus, Blastomyces dermatitidis.

- Bone involvement is the second most common manifestation of extrapulmonary blastomycosis, after skin involvement.

- Blastomycosis is often misdiagnosed and can mimic malignancy. A high degree of suspicion is needed for accurate diagnosis given delayed recognition of blastomycosis impairs the optimal prognosis. of recurrence, osteoarticular blastomycosis requires at least 12 months of treatment.

Contributors SK wrote the first draft of the manuscript. TK, JM and PS critically reviewed and revised the manuscript. All authors read and approved the final paper.

Funding The authors have not declared a specific grant for this research from any funding agency in the public, commercial or not-for-profit sectors.

Competing interests None declared.

Patient consent for publication Obtained.

Provenance and peer review Not commissioned; externally peer reviewed.

\section{ORCID iD}

Takaaki Kobayashi http://orcid.org/0000-0003-4643-4798

\section{REFERENCES}

1 Castillo CG, Kauffman CA, Miceli MH. Blastomycosis. Infect Dis Clin North Am 2016:30:247-64.

2 Chapman SW, Lin AC, Hendricks KA, et al. Endemic blastomycosis in Mississippi: epidemiological and clinical studies. Semin Respir Infect 1997;12:219-28.

3 Saccente M, Woods GL. Clinical and laboratory update on blastomycosis. Clin Microbiol Rev 2010;23:367-81.

4 Oppenheimer M, Embil JM, Black B, et al. Blastomycosis of bones and joints. South Med J 2007:100:570-8.

5 Wheat J, Wheat $\mathrm{H}$, Connolly $\mathrm{P}$, et al. Cross-Reactivity in Histoplasma capsulatum variety capsulatum antigen assays of urine samples from patients with endemic mycoses. Clin Infect Dis 1997;24:1169-71.

6 Chapman SW, Dismukes WE, Proia LA, et al. Clinical practice guidelines for the management of blastomycosis: 2008 update by the infectious diseases Society of America. Clin Infect Dis 2008;46:1801-12.

Copyright 2020 BMJ Publishing Group. All rights reserved. For permission to reuse any of this content visit https://www.bmj.com/company/products-services/rights-and-licensing/permissions/

BMJ Case Report Fellows may re-use this article for personal use and teaching without any further permission.

Become a Fellow of BMJ Case Reports today and you can:

- Submit as many cases as you like

- Enjoy fast sympathetic peer review and rapid publication of accepted articles

- Access all the published articles

Re-use any of the published material for personal use and teaching without further permission

Customer Service

If you have any further queries about your subscription, please contact our customer services team on +44 (0) 2071111105 or via email at support@bmj.com.

Visit casereports.bmj.com for more articles like this and to become a Fellow 